NBER WORKING PAPER SERIES

\title{
ACCCUMULA'IION AND GROWTH IN A TWO-COUNTRY \\ MODEL: A SIMULATION APPROACH
}

David Lipton

Jeffrey Sachs

Working Paper No. $57 \underline{2}$

\author{
NATIONAL BUREAU OF ECONOMIC RESEARCH \\ 1050 Massachusetts Avenue \\ Cambridge MA 02138 \\ October 1980
}

\begin{abstract}
This paper was presented at the NBER's 1980 Summer Institute program in International Studies. It is part of the NBER's research program in International Studies. We would like to thank participants in the NBER Summer Institute in International

Economics for helpful comments. This paper is a draft and is not for citation. Comments are most welcome. Any opinions expressed are those of the authors and not those of the National Bureau of Economic Research.
\end{abstract}


Accumulation and Growth

In a Two-Country Mode1:

A Simulation Approach

\title{
ABSTRACT
}

This paper analyzes saving and capital accumulation in a two-good growth model of two market economies in which economic agents optimize with perfect foresight. The goal is to present a model in which shortrun dynamics and the steady-state are soundly integrated. We stress the importance of asset markets as the linkage that transmits disturbances both internationally and intertemporally. While many components of the model described below can be found in the literature on optimal consumption, investment and international growth models, we provide a consistent synthesis. Our framework permits the analysis of structural adjustment in the global economy, and the dynamic effects of a wide range of public policies.

\author{
Mr. David Lipton \\ Mr. Jeffrey Sachs \\ Nationa1 Bureau of \\ Economic Research \\ 1050 Massachusetts Avenue \\ Cambridge, Massachusetts \\ 02138
}




\section{INTRODUCTION}

This paper analyzes saving and capital accumulation in a twogood growth model of two market economies in which economic agents optimize with perfect foresight. The goal is to present a model in which short-run dynamics and the steady-state are soundly integrated. We stress the importance of asset markets as the linkage that transmits disturbances both internationally and intertemporally. While many components of the model described below can be found in the literature on optimal consumption, investment and international growth models, we provide a consistent synthesis. Our framework permits the analysis of structural adjustment in the global economy, and the dynamic effects of a wide range of public policies.

The two-economy model outlined below includes the following features: (1) optimization by infinitely lived households who consume leisure and goods and who save by purchasing internationally traded claims to equity capital; (2) intertemporal optimization by value-maximizing competitive firms that make production and (irreversible) investment decisions, where capital formation is modeled as an adjustment process requiring real resources; (3) perfect foresight of households and entrepreneurs; (4) production of a single good in each country, which is traded internationally and which is an imperfect consumption substitute for the other country's good; and (5) perfect substitutability of the equity claims to the capital stock of each economy.

In the literature, we find many of these features in isolation but never together. Hamada [9] provides an optimal growth model 
but for a single, small economy. Two-country models typically include ad hoc savings behavior, with savings proportional to disposable income or disposable income and wealth (cf. [ 9], [ 7], [8], and [15]). One notable exception here is Buiter [5], who presents a two-country growth model with full dynamic optimization of households in an overlapping generations framework. Buiter asks how international differences in pure time preference affect accumulation, the balance of payments and welfare. The overlapping generations framework unfortunately cannot handle the short-run aspects of the adjustment problems that we treat. Obstfeld [14] presents a model of infinitely lived, optimizing households, such as ours, but he does not treat at all the issues of investment and growth.

Adjustment costs in investment were first introduced in the two-country growth model literature by Fisher and Frenkel [7], who posit a production possibilities frontier for each economy that contracts when capital formation is rapid. This feature, however, has not been widely adopted. Ruffin [15], for instance, assumes that capital may be transplanted instantaneously from one economy to the other in order to instantly equalize marginal products of capital across economies. In our model, the presence of adjustment costs in investment imply that unequal marginal products result in finite but differing rates of investment across economies. There is a determinate, and in fact optimal level of investment for each economy, which is shown to depend on Tobin's q. In our model, firms make investment decisions and households make consumption and saving decisions based largely on asset prices. Asset markets link households and firms and they guide an 
efficient intertemporal allocation of resources. With full optimization by all agents, the model permits straightforward welfare evaluations of alternative policies.

Perfect foresight on the part of economic agents ensures that asset prices and the current assessment of human wealth summarize information about expected events and that current allocation and accumulation decisions reflect these expectations. With the perfect foresight assumption, it is possible to analyze anticipated future disturbances and the differing effects of permanent versus temporary shocks. Of course, most models of two-country growth rely on static expectations, (cf. [8], [15], and again the exceptions of [14], [5]).

To maintain the purity of this model, we have sacrificed realism at many points. We expect that in further work realistic features may be added to analyze particular subsectors or institutions in the world economy. We feel however that there is a need for a canonical model in this field to serve as a benchmark for further study.

We confine our attention in this paper to three applications of the model: a study of the "transfer problem," an analysis of the international effects of balanced-budget fiscal policy, and an analysis of how improved productive technology in one country affects capital accumulation and production in both. This case has obvious relevance to the issue of OECD adjustment to growth in the newly-industrialized countries (NIC's).

Besides these three topics our model can handle a host of alternative applications. By incorporating provisions of corporate and 
personal tax laws, one can study the nature and extent of international transmission of domestic tax changes. By adding oil as an intermediate input in production and OPEC as an entity that sells oil and purchases goods, one can examine the impact of an oil price shock on the capital formation processes in the two developed economies (cf. [16]). Finally, the inclusion of money as an additional asset allows one to look at the interaction of monetary policies and the accumulation process in a global setting, and to model exchange rate dynamics.

Because of the assumption of perfect foresight, the model exhibits saddlepoint stability and poses a two-point boundary value problem. Since such problems do not typically yield analytical solutions, we solve the model through simulation, using the numerical method of "multiple shooting." ${ }^{1 /}$ Simulation parameters are selected from other work in the literature, and the importance to the model of our choice of parameters is scrutinized through sensitivity analysis. Though we rely heavily on simulation, our qualitative dynamic results can be established with theoretical arguments.

\section{THE MODEL}

The model we consider is that of a growing two-country world where each economy produces a single good, which is consumed domestically, sold to foreigners, and used for home capital formation. Firms produce goods and install capital so as to maximize firm valuation. Labor is immobile internationally. Capital formation is irreversible: once in place, capital may be reduced only through depreciation. 
Growing, infinitely lived households consume home and foreign goods and leisure to maximize an additively separable intertemporal utility function. Household income is consumed or saved in the form of equity in domestic and foreign firms. Equity is the sole store of value. There is free international trade in equities, as well as goods, and we assume that home and foreign equities are perfect substitutes. Thus, instantaneous real holding yields on equity defined in terms of the home good are equalized internationally. Let $r$ and $r *$ be the yield at home and abroad in own good units. Then

$$
r=r *-\dot{\pi} / \pi
$$

where $\Pi$ is the relative price of goods, $p / p^{*}$, and "*" denotes the foreign country.

Through equity purchases by households, the world pool of savings is channeled to profitable investment projects without regard to the national origin of the savings. International trade in goods and equity in this model allows households to satisfy desires for goods unavailable at home and to shift consumption streams over time through international borrowing and lending. If on net, one country spends more than its income, running a current account deficit, the dissaving is matched by a capital account surplus, equaling the sale of equity claims to the foreign economy.

Goods market equilibrium in each country requires that output supply equals goods demand:

$$
\begin{aligned}
& Q=C_{D}+I+G+C_{M}^{*} \\
& Q^{*}=C_{D}^{*}+I^{*}+G^{*}+C_{M}
\end{aligned}
$$


where $Q$ is output; $C_{D}$ is demand for the domestically produced good; I is investment expenditures; $G$ is government spending; and $C_{M}$ is demand for the non-domestically produced good. Here, and henceforward, quantity variables are written in intensive form, per member of the home country household, $\mathrm{L}_{f}$. Households in each country grow at the same rate $n$, so the ratio of home to foreign population is constant. Labor market equilibrium in each country occurs when firm labor demand equals household labor supply. Households choose leisure and labor supply to maximize utility. The labor market clears continuously; variations in employment in this model are equilibrium shifts only.

We now turn to a detailed description of firm and household behavior within this framework and explain the dynamics of the model. The model is written down in Table 1 . We will refer to the pieces of this model as we continue in the rest of section 2 .

\section{A. The Firm}

The theory of investment behavior used in the model combines the neo-classical approach associated with Jorgenson [11] and the "q" approach associated with Tobin [17]. This cost-of-adjustment theory of investment was first developed by Lucas [13] and Treadway [18], and has been elaborated in Abel [1], Blanchard [4] and Hayashi [10]. In the theory presented, investment depends upon Tobin's 'q', the ratio of the market value of equity capital in the firm to its replacement cost. Investment is described as an increasing function of $q$ and $I>0$ whenever $q$ is greater than one. We will see that $q$ summarizes all relevant market information for the firm's investment strategy. In our model each country uses its own good as the investment good. Thus the replacement cost of capital is just the output price. $q K$ is the market value of the firm in units of the home good. 


\section{TABLE 1}

\section{THE COMPLETE MODEL}

A. The Household

$$
\begin{aligned}
& \text { (1.1) } \quad \mathrm{p}_{\mathrm{C}} \mathrm{C}=(\delta-\mathrm{n}) \mathrm{A} \\
& \text { (1.2) } \quad \mathrm{p}_{\mathrm{C}}^{*} \mathrm{C}^{*}=(\delta-n) \mathrm{A}^{*} \\
& \text { (1.3) } \quad A=A^{F}+H \\
& \text { (1.4) } \quad A^{*}=A^{F^{*}}+H^{*} \\
& \text { (1.5) } \quad A^{F}=q K+q * Z / \Pi \\
& \text { (1.6) } \quad \mathrm{A}^{\mathrm{F}}=\mathrm{q}^{*}\left(\mathrm{~K}^{*}-\mathrm{Z}\right) \\
& \text { (1.7) } \quad \dot{H}=(r-n) H-w(1-\tau) \\
& \text { (1.8) } \quad \dot{H}^{*}=(r-n) H^{*}-w^{*}\left(1-\tau^{*}\right) \\
& \text { (1.9) } \quad \lim _{t \rightarrow \infty} e^{-(r-n) t} H=0 \\
& \text { (1.10) } \quad \lim _{t \rightarrow \infty} e^{-\left(r^{*}-n\right) t} H^{*}=0 \\
& \text { (1.11) } \quad C_{D}=C_{D}(\pi, w(1-\tau)) \cdot p_{C} C \\
& \text { (1.12) } \quad C_{M}=C_{M}(\pi, w(1-\tau)) \cdot p_{C} C \\
& \text { (1.13) } \quad C_{D}^{*}=C_{D}^{*}\left(\pi, w^{*}\left(1-\tau^{*}\right)\right) \cdot p_{C}^{*} C^{*} \\
& \text { (1.14) } \quad C_{M}^{*}=C_{M}^{*}\left(\Pi, w^{*}\left(1-\tau^{*}\right)\right) \cdot p_{C}^{*} C^{*} \\
& (1.15) \quad(1-L)(1-\tau)=p_{C} C-C_{D}-C_{M} / \Pi
\end{aligned}
$$



(1.16)
$\left(1-L^{*}\right)(1-\tau)=p_{C}^{*} C^{*}-C_{D}^{*}-\Pi C_{M_{i}^{*}}^{*}$
$(1.17)$
$p_{c}=p_{c}(w, \pi)$
$(1.18)$$$
\mathrm{p}_{\mathrm{C}}^{*}=\mathrm{p}_{\mathrm{C}}^{*}\left(\mathrm{w}^{*}, \pi\right)
$$

B. The Firm
$(1.17)$
$\mathrm{Q}=\theta \mathrm{K}^{1-\alpha_{\mathrm{L}}}{ }^{\alpha}$
(1.18) $\quad Q^{*}=\theta^{*} K^{* 1-\alpha} L^{* \alpha}$
(1.19) $\quad \mathrm{L}=(\mathrm{w} / \alpha \theta)^{1 / 1-\alpha} \cdot \mathrm{K}$
$(1.20)$
$L^{*}=\left(w^{*} / \alpha \theta^{*}\right)^{1 / 1-\alpha} \cdot K^{*}$
$(1.21)$
$I=J(1+\phi(J / K))$
$(1.22)$
$I *=J^{*}\left(1+\phi^{*}\left(J^{*} / K^{*}\right)\right)$
(1.23)
$J=J(q) \cdot K$
(1.24)
$J^{*}=J^{*}\left(q^{*}\right) \cdot K^{*}$
$(1.25)$
$\dot{K}=J(q) K-(d+n) \cdot K$
$(1.26)$
$\dot{K}^{*}=J^{*}\left(q^{*}\right) K^{*}-(d+n) \cdot K^{*}$

C. Asset Market Equilibrium
$(1.27)$
$r=D i v / q K+\dot{q} / q$
$(1.28)$
$r^{*}=\operatorname{Div} * / q^{*} K^{*}+\dot{q} * / q^{*}$ 
$-9-$

(1.29) $\quad r=r^{*}-\dot{\Pi} / \Pi$

(1.30) Div $=Q-w L+q(n K+\dot{K})-I$

(1.31) Div* $=Q^{*}-\mathrm{w}^{*} \mathrm{~L}^{*}+\mathrm{q}^{*}\left(\mathrm{n} \mathrm{K}^{*}+\mathrm{K}^{*}\right)-\mathrm{I}^{*}$

(1.32) $\quad \lim _{t \rightarrow \infty} e^{-r t} q=0$

(1.33) $\quad \lim _{t \rightarrow \infty} e^{-r^{*} t} q^{*}=0$

D. Output Market Equilibrium

(1.34) $Q=C_{D}+I+G+C_{M}^{*}$

(1.35) $\quad Q^{*}=C_{D}^{*}+I^{*}+G^{*}+C_{M}$

E. Balance of Payments

(1.36) $\quad C A=Q+\left(r^{*}-\dot{q}^{*} / q^{*}\right) q^{*} Z / \Pi-C_{D}-I-G-C_{M} / \Pi$

(1.37) $\quad \dot{z}=\left(\pi / q^{*}\right) C A-n z$

F. Government Sector

$(1.38)$

$G=\tau W L$

$(1.39)$

$\mathrm{G}^{*}=\tau^{*} \mathrm{~W}^{*} \mathrm{~L}^{*}$ 
Let $\mathrm{MH}$ be the total manhours of labor supply, and $\mathrm{L}\left(=\mathrm{MH} / \mathrm{L}_{\mathrm{f}}\right)$ be the labor supply per person. Then output (per $L_{f}$ ) is given by the neoclassical CRS production function $Q=F[K, L]$. In the simulation, we will assume a Cobb-Douglas form for $Q$.

We assume that the firm acts to maximize market value. Our discussion of the firm thus begins with the equations of firm valuation. For an equity owner, the instantaneous yield on capital is the sum of the dividend yield and capital gains:

$$
\mathrm{r}=\mathrm{Div} / \mathrm{qK}+\dot{\mathrm{q}} / \mathrm{q}
$$

where Div is total dividends paid by the firm. Because the value of the firm $V$ is $q \cdot K$ we can re-write (3) as:

$$
\dot{V} / \mathrm{V}-\dot{K} / \mathrm{K}+\mathrm{Div} / \mathrm{V}=\mathrm{r}
$$

We assume that the firm issues new equity to finance capital formation. $2 /$ At any instant, the new issues raise funds in the amount $q(n K+\dot{K})$. It is easy to show that dividends are:

(5) $\quad$ Div $=Q-w L+q(n K+\dot{K})-I$

where $w$ is the gross product wage paid. Substitution of equation (5) into (4) gives:

$$
\dot{V} / V+\frac{Q-w L-I}{V}=r-n
$$

and integration yields the firm valuation integral

$$
V=q K=\int_{0}^{\infty}(Q-w L-I) e^{-\int_{0}^{t}(r(s)-n) d t} .
$$

$V$ is maximized subject to constraint on capital accumulation:

$$
\dot{\mathrm{K}}=\mathrm{J}-(\mathrm{d}+\mathrm{n}) \mathrm{K}
$$


where $J$ is the gross capital formation and $d$ is the rate of depreciation. We assume that investment expenditures I differ from capital formation $J$ because of adjustment costs in capital installation. Let $\phi$ represent per unit adjustment costs to capital formation. Total investment expenditure is given by:

$$
I=(1+\phi) \mathrm{J}
$$

Following Hayashi [10] and Treadway [18], we assume that $\phi$ is a . rising function of the rate of capital formation relative to the existing capital stock:

$$
\phi(\cdot)=\phi(J / K) \quad \phi^{\prime}>0
$$

Firms in each economy are identical price-taking competitors, that maximize firm values. Maximizing (7) subject to (8) gives the following first order conditions:

$$
\begin{aligned}
& \text { (11) } \quad \mathrm{w}=\mathrm{Q}_{\mathrm{L}} \\
& \text { (12) } \lambda=1+\phi(J / K)+(J / K) \phi^{\prime}(J / K) \\
& \text { (13) } \quad \dot{\lambda}=(\mathrm{r}+\mathrm{d}) \lambda-\left[\mathrm{Q}_{\mathrm{K}}+(\mathrm{J} / \mathrm{K})^{2} \phi^{\prime}(\mathrm{J} / \mathrm{K})\right] \\
& \text { (14) } \dot{K}=J-(d+n) K
\end{aligned}
$$

$\lambda$ is the shadow value of capital from constraint (8). Using the production function and (11) we may write labor demand as a function of the wage and capital stock. In the Cobb-Douglas case, labor demand is given by (1.19) and (1.20) in Table 1. 
From (12) we see that the firm will choose the level of gross capital formation to equate the marginal benefit of capital in place, $\lambda$, with the marginal investment expenditure, $1+\frac{\mathrm{d}}{\mathrm{dJ}}[\phi(\cdot) \mathrm{J}]$. The shadow price exceeds one whenever gross capital formation is positive so that adjustment costs push investment expenditure above the acquisition value of the capital itself.

With the linear homogeneous production and adjustment technology that we have assumed it is easy to show that the shadow price equals the market price of equity, that is $\lambda=q$. Using equations (11) - (14) we may check that all aspects of the firm's optimal program are linear in $K$. That is, if a firm with capital stock $\mathrm{K}$ hires $\mathrm{L}$ and invests $\mathrm{J}$, a firm with $\varepsilon \mathrm{K}$ will hire $\varepsilon \mathrm{L}$ and invest $\varepsilon J$. Thus, the value of the firm rises in proportion to $K$, since $V$ in (7) is linear in $L, K$, and $J$. Since $\lambda=\partial V / \partial K$ and $V$ is 1 inear in $\mathrm{K}, \mathrm{V}=\lambda \mathrm{K}$. But by definition, $\mathrm{V}=\mathrm{qK}$. Thus $\mathrm{q}=\lambda$. A more formal proof of this relation may be found in Hayashi [10]. In sum, the equity price that the firm observes in the market place also equals the shadow price of capital that guides the firm's investment decisions.

One key consequence of this equivalence is that an investment function for the firm can be written in terms of $q$, an observable price. Inverting equation (12) and presuming linear adjustment costs $\phi(\cdot)=(b / 2) \mathrm{J} / \mathrm{K}$, we can write:

(15) $\mathrm{J} / \mathrm{K}=(\mathrm{q}-1) / \mathrm{b}$.

The managers of a firm can simply observe the market equity price, $q$, and select a capital formation rate, J/K. This is the essence 
of Tobin's approach embedded in an adjustment cost model of firm investment.

Equation (13) describes the transition path for the shadow price of capital. It can be shown that (13) is an equivalent expression for the holding yield on equity in ( 3 ).

Equation ( 8 ) describes the path of capital accumulation and is repeated in Table 1 for each country as equations (1.25) and (1.26).

B. The Household

Households maximize the discounted value of instantaneous utility $U(\cdot)$ weighting by the size of the household at any moment, $\mathrm{L}_{\mathrm{f}}$ :

$$
\int_{0}^{\infty} U\left(C_{D}, C_{M}, \quad(1-L)\right) L_{f} e^{-\delta t} d t
$$

Instantaneous utility is a function of domestic good consumption, foreign good consumption, and leisure. (16) is an intertemporal homothetic utility function under the assumption that $U\left(C_{D}, C_{M},(1-L)\right)$ can be rewritten as:

$$
\begin{array}{ll}
(17)\left(C_{D}, C_{M},(1-L)\right](1-\sigma) /(1-\sigma) & \sigma \neq 1 \\
\log \left[C\left(C_{D}, C_{M},(1-L)\right]\right. & \sigma=1
\end{array}
$$

with C linear homogeneous in its arguments. We adopt this assumption. In this case, the household's decision problem is separable: at any moment, the household decides on the level of $C$ and the level of savings. Subsequently, for given $C$, the household decides upon the components $C_{D}, C_{M}$, and $(1-L)$, based on the momentary relative prices of these goods. This separability, and other technical aspects of the consumer problem, are discussed in Appendix 1. $\underline{3}$ / 
Given the linear homogeneity of $C$, there is a true price index $p_{c}$ that is itself linear homogeneous in the prices of $C_{D}, C_{M}$, and $(1-L)$. The price index may be defined by the property that

$$
\begin{aligned}
p_{C} C= & \min _{C_{D}}, C_{M},(1-L) \quad C_{D}+C_{M} / \pi+(1-\tau) w(1-L) \\
& \text { such that } \quad C\left(C_{D}, C_{M}, 1-L\right)=\bar{C} .
\end{aligned}
$$

For any $C, p_{C} C$ is the value of total instantaneous consumption, equal to $C_{D}+C_{M} / \pi+(1-\tau) w(1-L)$. The first stage of the consumer optimization problem is to maximize $\int_{0}^{\infty} e^{-\delta t} U(C) d t$ such that the discounted value of $p_{C} C$ equals current wealth $A$. That is, the budget constraint is given by:

$$
A=\int_{0}^{\infty}\left(p_{c} c\right) e^{-\int_{0}^{t}(r(s)-n) d s} d t .
$$

Time differentiation of this constraint yields the dynamic equation:

$$
\dot{A}=(r-n) A-p_{C} C \text {, with } \lim _{t \rightarrow \infty} e^{-r t} A=0 \text {. }
$$

$A$ is the sum of financial wealth $A^{F}$ and human wealth $H$. Since we are imputing consumption expenditures to the household's leisure, in the amount of $(1-\tau) w(1-L)$, we must treat the human wealth component of $A$ in a consistent manner. Human wealth must be defined as the discounted value of post-tax potential labor income, for a household that takes no leisure, i.e., L $\equiv 1$. This is equivalent in a static model to measuring "full income" at the point of zero leisure. Thus, we have

$$
H=\int_{0}^{\infty} w(1-\tau) e^{-\int_{0}^{t}(r(s)-n) d s} d t .
$$

Time differentiation of (2l) yields $\dot{H}=(r-n) H-w(1-\tau)$, with $\lim _{t \rightarrow \infty} e^{-r t} H=0$. 
Financial wealth is simply the sum of the values of home and home-held foreign equity (Z):

$$
A^{F}=q K+q * Z / \Pi
$$

We now maximize (16) subject to (19), for which it is easy to show:

$$
\sigma \frac{\dot{\mathrm{C}}}{\mathrm{C}}=\mathrm{r}-\delta-\dot{\mathrm{p}}_{\mathrm{C}} / \mathrm{p}_{\mathrm{C}}
$$

Importantly, $C$ is $r$ ising when the real interest rate $r-\dot{p}_{C} / p_{C}$ is greater than the rate of time discount. When $r-\dot{p}_{c} / p_{c}$ rises above $\delta$ in some time interval: the marginal rate of substitution of consumption will equal the interest rate only if consumption is rising over the interval. With additively separable and homethetic utility, consumption at the later point must exceed consumption at the earlier point to drive down marginal utility at the later point relative to the initial point.

For simplicity we restrict consideration here to the logarithmic case of $\sigma=1$ and $U(C)=\operatorname{Ln}(C)$, and discuss the more general case in Appendix 1. The logarithmic utility function proves simple to use for it implies that $\mathrm{p}_{\mathrm{C}} \mathrm{C}$ is a fixed proportion of wealth at any instant, where the factor of proportionality for the growing household is the discount rate less the household growth rate:

$$
\mathrm{p}_{\mathrm{C}} \mathrm{C}=(\delta-\mathrm{n}) \mathrm{A}
$$

To see this, consider the solution to the differential equation (23). Since $\left(\dot{p}_{c} c\right) /\left(p_{c} c\right)=\dot{p}_{c} / p_{c}+\dot{C} / C$, we have from (23) that

$$
\left(p_{c} C\right)=(r-\delta)\left(p_{c} C\right)
$$


Solving this equation, we find

$$
p_{c} C=p_{C}(0) C(0) e^{\delta_{0}^{t}}(r(s)-\delta) d s
$$

When (26) is substituted into the intertemporal budget constraint (19), we have

$$
A(0)=\int_{0}^{\infty} p_{C}(0) C(0) e^{-(\delta-n) t} d t
$$

which reduces immediately to (24).

Total consumption for the individual at any time is thus entirely dependent on current wealth. In the more general case of Appendix 1, when $\sigma \neq 1, \mathrm{p}_{\mathrm{c}} \mathrm{C}$ also depends on the future paths of $p_{c}$ and $r$. The asset markets which value equity and the household's foresight over labor income provide an assessment of wealth which guides the household in its choice of total consumption.

The components of total consumption in any period may be derived from standard static optimization, and depend on the relative goods price, $\pi$, the net-of-tax wage, $w(1-t)$ and total expenditure $\mathrm{p}_{\mathrm{C}} \mathrm{C}$.

$$
\begin{aligned}
& C_{D}=C_{D}(\pi, w(1-\tau)) \cdot\left(p_{C} C\right) \\
& C_{M}=C_{M}(\pi, w(1-\tau)) \cdot\left(p_{C} C\right) \\
& (1-L)(1-\tau)=p_{C} C-C_{D}-C_{M} / \pi
\end{aligned}
$$

In Table 1 , domestic and import demands, $C_{D}$ and $C_{M}$ enter the goods market conditions (1.34) and (1.35). Labor market equilibrium requires that household labor supply equals firms' labor demand. 


\section{Balance of Payments}

For each country the current account CA must equal the opposite of the capital account. The current account is income less absorption, where income is the sum of output and dividend payments on claims to foreign equity. Note that this national accounting definition of income excludes accrued but unconstructed capital gains on the foreign equity. Since the dividend yield is $r^{*}-\dot{q}^{*} / q^{*}$, we write

$$
C A=Q+\left(r^{*}-\dot{q}^{*} / q^{*}\right) q^{*} Z / \pi-C_{D}-I-G-C_{M} / \pi
$$

where $z$ denotes the per capita number of foreign securities held domestically. The change in $z$ is governed by the current account surplus (or capital account deficit), with

$$
\dot{z}=\left(\pi / q^{*}\right) C A-n Z \text {. }
$$

We may note from (32) that the CA will not in general be zero in the steady state. If the home economy is a net creditor of the rest of the world (i.e., $z>0$ ), the current account must be in surplus to allow for widening of the foreign claims for the growing househo1d. Thus, $C A=n Z q^{*} / \Pi>0$. For the case $z<0$, the current account will be in deficit in the steady state.

\section{Government}

Government revenues in the current context are simply the proceeds from proportiona 1 labor taxation at rate $\tau$. Presuming balanced budget government spending at all points on home goods, per capita government expenditure is

$$
G=\tau w L
$$


Note that we assume that $G$ does not enter into household utility, (or less restrictively, that utility from $G$ is additively separable from $U(\cdot))$. In the simulation we take $\tau$ as the policy instrument, with $G$ adjusting to preserve budget balance.

\section{PROPERTIES OF THE MODEL}

The pieces of the model are now in place, and we may turn to some of the model's important characteristics. Most importantly, the global economy is pareto efficient across economies and over time. For given $\int_{0}^{\infty} e^{-\delta t} U(\cdot) d t=\bar{U}$, the foreign household utility level $U^{*}=\int_{0}^{\infty} e^{-\delta t} U^{*}(\cdot) d t$ is maximized. This fact may be demonstrated by arguments similar to those in [2]. Several relations are key to this efficiency result. Because of perfect foresight and efficient asset markets, resources are set aside for capital formation whenever the shadow utility of an extra unit of investment exceeds the current household marginal utility of consumption of those resources. Marginal rates of substitution over time equal marginal rates of transformation within each economy. Moreover, intertemporal marginal rates of substitution are equalized across households in the two countries through household savings behavior. This equality forces equalization of the marginal rates of transformation at home and abroad.

The next issue is the subtle problem of solving for the dynamic paths of adjustment in this model. Judging from the differential equations in Table 1 , it appears the system is an eight-dimensional non-linear differential equation system, in $K, K^{*}, Z, q, q^{*}, H, H^{*}$ and $\pi$. In fact these eight variables do not provide the minimal state-space representation of the model, since the dynamic and 
static equations may be used to solve for $\dot{\pi}$ and $\dot{q}$ * in terms of the levels and time derivatives of $K, K^{*}, Z, q, H$, and $H^{*}$. In $f a c t$, we have a six-dimensional system.

If we know at any time the values of these six variables and the path of anticipated future exogenous variables, the model may be integrated forward to solve for the future paths of all endogenous variables. The problem, however, arises that the value of $q, H$, and $H^{*}$ are unknown at any time $t$. As is customary in these models, the values of these three asset variables are defined not by the history of the system but by the future paths of certain endogenous variables. Thus, $H$ equals the discounted value of future wages, and $q$ equals the discounted value of the firm's future cash flow. An apparent computational dilemma arises: we must know future wages to determine $H$, but we must know $H$ in order to integrate the system forward to find the future wages.

Fortunately, the problem may be restated in more conventional form, as a two-point boundary value problem. The unique $\mathrm{H}$ which equals the discounted value of future wages is also the unique $H$ from which forward integration of the economy settles down to a steady state. In other words, the dynamic system is saddlepoint stable; starting from any but a unique set of $q, H$ and $H^{*}$ the forward integration diverges from a steady state. Starting from the point that does converge, the arbitrage conditions on the asset prices guarantee that they represent the appropriate dis-

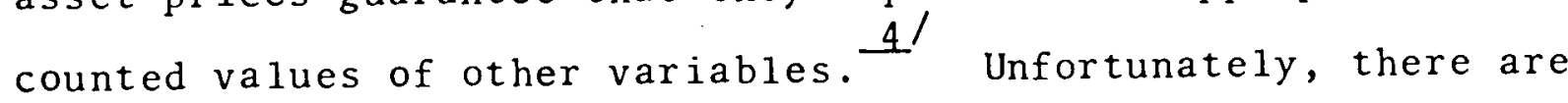
no general analytic methods for finding the initial values of $\mathrm{H}, \mathrm{H}^{*}$ and $\mathrm{q}$ that lead to the balanced growth equilibrium. In the simulations described below we have used a numerical method called 
"multiple shooting" for solution to the problem. The method is we 11 known in the physical sciences, but only recently has been introduced as a technique for solving rational expectations models (see [12]). Described simply, an initial guess for the three variables is made, and the model is integrated forward from this point. The path will be explosive as long as the initial guesses are not the true values. At a distant terminal date, one assesses the extent to which the steady-state values have been missed by forward integration. Newton's method is then used to adjust the initial guesses so that forward integration will more accurately approach the steady state. Iteration will provide convergence to the unique initial values, as long as the starting guess is sufficiently close. The method is "simple" shooting if the forward integration is made over the whole interval from the initial to terminal data. Because of the saddlepoint nature of our model the simple procedure will often fail, as the economy's path diverges too quickly to permit numerical integration to the terminal date. Multiple shooting harnesses the explosiveness by dividing the time horizon into shorter intervals, for which interim guesses of the predetermined and non-predetermined variables are made. Newton's method is performed on an extended vector of guesses. Since the model is no longer integrated forward over the entire time horizon of the simulation, the explosiveness is kept under control. For details, see [12].

One reason to construct a dynamic optimizing growth model is to examine the entire path of economic variables, and to look beyond steady-state comparative statics. Indeed in this model no particular welfare implications emerge from an examination of steady-states 
because household utility is governed by the entire path of consumption. Nonetheless a look at the model's steady-state characteristics provides a helpful reference point against which we can measure movements caused by particular shocks, and can indicate where the system will be heading after a disturbance.

The condition for consumer equilibrium in (23) holds that full consumption is constant only when the endogenous interest rate is equal to the fixed rate of pure time preference $\delta$. Thus, in models of infinitely lived households with additively separable utility and constant $\delta, r$ returns to $\delta$ regardless of the shocks that hit the economy. Put otherwise, saving is perfectly elastic at the interest rate $\delta$ in the long run. The equality of $r$ and $\delta$ is the steady-state modified golden rule of the economy.

With the long-run interest rate fixed, the steady-state capital-labor ratio is strictly determined by the production technology and adjustment costs of firms. Since steady-state growth requires the rate of capital formation $\bar{J} / \bar{K}$ to equal $n+d$, long-run $q$ and $q^{*}$ must be high enough to elicit such investment. In the longrun, $q$ and $q^{*}$ exceed 1.0 , and we see from (15) that $\bar{J} / \bar{K}=n+d$ implies $\bar{q}=1+b(n+d)$.

From the asset market equilibrium conditions and $\bar{r}=\delta$, we may note that $\dot{q}=0$ and $\dot{q}^{*}=0$ imply $(\overline{\mathrm{Div}} / \overline{\mathrm{K}})=\delta \overline{\mathrm{q}}$ and $\left(\overline{\operatorname{Div}} \overline{\mathrm{K}}^{\star}\right)=\delta \bar{q}^{*}$. Let us turn to the expression for Div/K, with the goal of showing that steady-state $K$ is uniquely determined by $\delta$ and $\bar{q}$. Since Div $=Q-w L+q(n K+\dot{K})-I$, and $I=J(1+\phi(J / K))$, steady-state Div can be written as $\overline{D i v}=\bar{Q}-\bar{w} \bar{L}+\bar{q}(n \bar{K})-\bar{J}(1+\phi(n+d))$. Thus, $\overline{\operatorname{Div}} / \overline{\mathrm{K}}$ equals $(\overline{\mathrm{Q}}-\mathrm{w} \overline{\mathrm{L}}) / \overline{\mathrm{K}}+n \bar{q}-(\mathrm{n}+\mathrm{d})(1+\phi(\mathrm{n}+\mathrm{d}))$. From the Euler condition $Q=F_{L_{1}}{ }+F_{K} K$, and the labor demand relation 
$F_{L}=w$, we may further re-write $\overline{\operatorname{Div}} / \bar{K}$ as $F_{K}-n \bar{q}-(n+d)(1+\phi(n+d))$. Long-run equilibrium requires that this equal $\delta \bar{q}$, or that $F_{K}=(n+\delta) \bar{q}+(n+d)(1+\phi(n+d))$. Since $F_{K}$ is a function of the capital-labor ratio, we may find $(\overline{K / L})=F_{K}^{-1}[(n+\delta) \bar{q}+(n+d)(1+\phi(n+d))]$. Obviously, a paralle 1 expression for $\left(\overline{K^{*} / L^{*}}\right)$ exists.

Now the product wage is also set by $F_{K}$ condition, since $w=F_{L}=g\left(F_{K}\right)$ for a function $g\left(g^{\prime}<0\right)$ defining the factor price frontier. Per capita human wealth is the capitalization of the net-of-tax wage flow:

$$
H=w(1-\tau) /(r-n)
$$

Although the capital-labor ratio and wage are set, the separate components of $\overline{\mathrm{K}} / \overline{\mathrm{L}}, \overline{\mathrm{K}}$ and $\overline{\mathrm{L}}$, are yet to be determined. In addition we must find the steady-state terms of trade, $\pi$, and the world distribution of equity ownership.

Total world equity wealth is given by $q K+q^{*} K^{*} / \pi$, with home wealth $q K+q^{*} Z / \Pi$ and foreign wealth $q^{*}\left(K^{*}-Z^{*}\right)$. The level of home ownership of $K^{*}$, denoted by $Z$, is dynamically determined in the model. It depends on the entire transition path of the two economies after a disturbance. For example, a transfer payment from one economy to the other starting from steady-state will not result in a return to the initial wealth distribution over time, as in other models with ad hoc savings (see, for example [15]). We cannot readily solve for steady-state $Z$ analytically, but we can solve for the remaining steady-state variables for a given $\bar{z}$. We do this first, and then examine the effects of a shift in $\bar{z}$ on the equilibrium. 


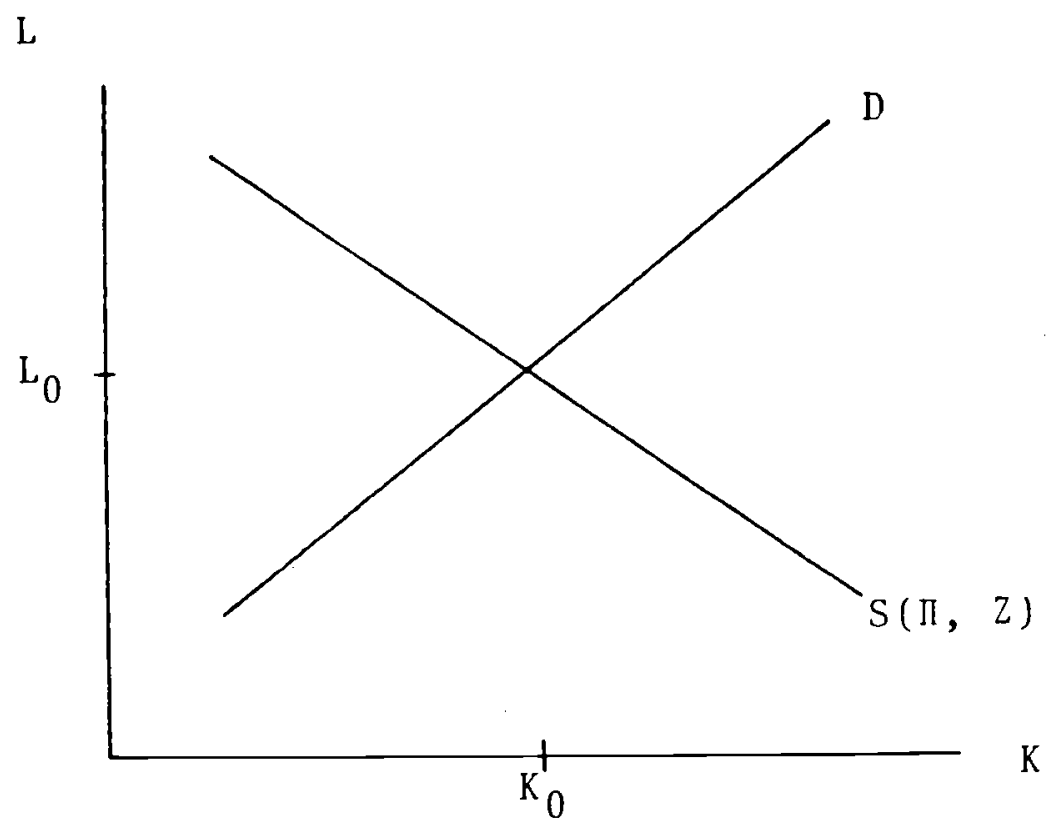

FIGURE 1. Partial Equilibrium Diagram of the Labor Market

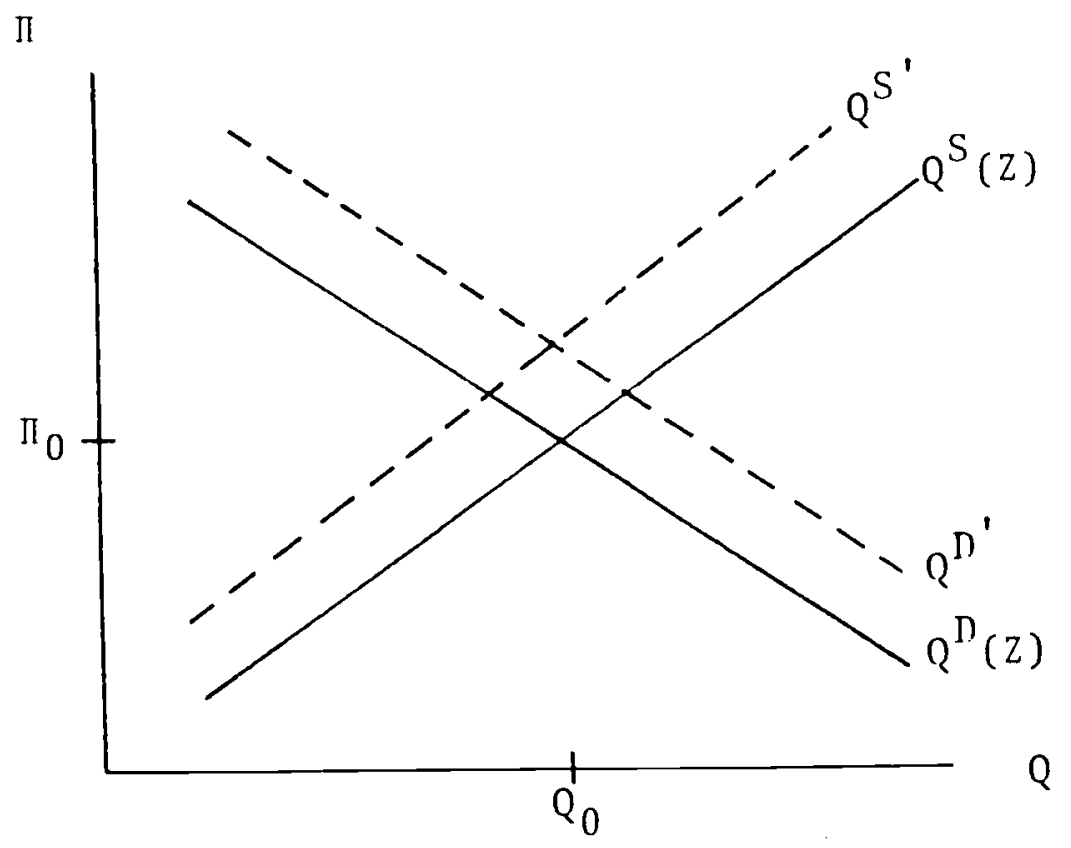

FIGURE 2. Partial Equilibrium Diagram of the Domestic Output Market 
In the cases where labor is inelastically supplied, i.e., $L \equiv 1$ we have $\bar{K} / \bar{L} \equiv \bar{K}$, so the capital stock per person is fixed by the arbitrage condition shown earlier. When $Z$ is set, wealth and full consumption are determined in each country and the equilibrium relative price, $\bar{\pi}$, emerges from the goods market equilibrium conditions, equations (2a) and (2b).

When leisure enters the utility function, one must look to the labor market to find, $\bar{K}, \bar{K}^{*}, \bar{L}, \bar{L}^{*}$, and $\bar{\Pi}$. Here a set of diagrams shows the simultaneous determination of $\bar{K}$ and $\bar{L}$. Consider the supply and demand for labor at different levels of $\bar{K}$, holding $\bar{\Pi}$ and $\bar{Z}$ constant, and using the steady-state relationships for $\bar{q}$ and $\bar{H}$ that we have so far adduced. Since $\bar{K} / \bar{L}$ is fixed by $\delta$, labor demand (DD) as a function of $\bar{K}$ is a ray from the origin in Figure 1 . Also, with leisure a normal good, and wealth increasing in $\bar{K}$ for given $\bar{Z}$ and $\bar{\Pi}$, labor supply (SS) is a negatively sloped function of $\bar{K}$. An increase in $\bar{Z}$ shifts the SS schedule down, due to the income effect on leisure of greater wealth. An increase in $\bar{\Pi}$ shifts the SS schedule up, through an income effect and substitution effect that work in the same direction. Higher $\bar{\Pi}$ raises the home real wage by reducing real import prices at any product wage $\bar{w}$, thus causing a substitution effect towards work. Also, higher $\bar{\Pi}$ reduces the value of wealth in foreign claims $q * \bar{Z} / \bar{I}$, and thus reduces the demand for leisure. In sum, the equilibrium level $\bar{L}$ shifts up with $\bar{\Pi}$ and down with $\bar{Z}$.

Now, output is $Q=F[\bar{K}, \bar{L}]$ and by linear homogeneity, $\bar{Q}=F[\bar{K} / \bar{L}] \cdot \bar{L}$. Since $\bar{K} / \bar{L}$ is fixed by $\delta$, steady-state $\bar{Q}$ is linear in $\bar{L}$. Output market equilibrium for the home good is shown in 
Figure 2, again drawn for given $\bar{Z}$. Output supply rises in $\bar{\pi}$ for reasons just described, while steady-state output demand can be shown to fall with high $\bar{\pi}$, given substitution in consumption towards the foreign good. A transfer towards the home country in the form of higher $\bar{Z}$ shifts the $Q^{D}$ schedule up, because the home household has a higher propensity than the foreign household to consume the home good. We have already seen that a rise in $\bar{z}$ shifts the $Q^{S}$ schedule up as leisure-taking increases.

The effect of a transfer payment is illustrated by the dotted lines. Since $Q^{D}$ and $Q^{S}$ both shift up, $\bar{\pi}$ must rise, while the effect on total output is ambiguous.

A similar ambiguity arises in consideration of a balancedbudget tax increase. We assume throughout that fiscal spending falls entirely on the home good, so a shift in taxes that raises $G$ and reduces $C$ tends to increase demand for the home good at given $\pi$. Thus, a tax increase shifts the $Q^{D}$ schedule up. The effect of the higher tax on $Q^{S}$ is of course ambiguous, as the income effect on labor supply (or leisure taking) raises $Q^{S}$ while the substitution effect tends to reduce $Q^{S}$. We assume a fairly high elasticity of substitution between leisure and goods (see Appendix 2) so that the substitution effect dominates, and $Q^{S}$ shifts up. Again $\bar{\pi}$ unambiguously rises while $\bar{Q}$ may rise or fall. Note importantly that this steady-state treatment is incomplete, as changes in $G$ may induce shifts in $\bar{Z}$ over an adjustment path, causing further shifts in the $Q^{D}$ and $Q^{S}$ schedule. We cannot avoid the dynamic analysis, then, in determining the full steady-state results. 
It should be clear for the tax and transfer problems as well as the technology shock that the results depend crucially on differential consumption behavior at home and abroad and on the nature of labor supply. To see how these factors affect the paths of adjustment we will simulate the model under a variety of assumptions, contrasting the cases of (1) elastic versus perfectly inelastic labor supply; and (2) imperfect versus perfect substitutability (i.e., fixed $\pi$ ) in consumption. The case of perfect substitutability is a special case of identical household preferences at home and abroad. Notice that for the tax, transfer and technology experiments we may readily isolate the pure effects of labor supply or varied tastes across countries.

\section{SIMULATION RESULTS}

This section of the paper examines the dynamic paths of the variables of the model via a simulation study. The simulations show the dynamic effects of (1) a transfer of financial capital from the foreign to the home country; (2) an unanticipated fifty percent balanced-budget reduction in the foreign labor tax rate; and (3) a neutral five-percent improvement in foreign technology. In each case we show the sensitivity of the dynamic path to the inclusion of leisure in the utility function and to the presence of two goods in the model. These are features which have often been excluded from other studies. See Appendix 2 for a list of parameter values and initial steady-state values of variables used in the simulations. 
CASE 1: Transfer of Equity Claims to Home Economy

The first set of simulations treats the case of a transfer of financial claims of foreign capital from foreign equity holders to home equity holders. We model, for illustration, a sizable transfer of claims, equalling 40 percent of the foreign holdings of foreign capital. Note that because of the predominance of human wealth, this transfer (at initial prices) represents only a 5.6 percent reduction in the wealth of the foreign country.

To begin with the simplest application of the model, consider the case where the home and foreign good are identical, and where leisure does not enter the utility function, so that labor is inelastically supplied. After the transfer, the international economy moves immediately to a new steady state: the 5.6 percent wealth decrease abroad leads to a proportionate decline in foreign consumption while the wealth increase at home leads to a proportionate rise in home consumption. The fact that the economies adjust immediately to the new steady-state growth path follows from the assumption of constant and equal rates of time discount across economies. At the initial interest rate, home consumption rises by $\mathrm{dC}=(\delta-n) q^{*} \mathrm{dz}$, while foreign consumption falls by an equal amount. Since world output supply remains fixed, total demand continues to equal total supply at the initial interest rate. Clearly, $\operatorname{Div} / \bar{q} K=r=\operatorname{Div} * / \bar{q}^{*} K$ continues to hold, so equity prices and the capital stock remain in equilibrium.

The only additional effect of the change in $Z$ is a slight adjustment in the composition of the balance of payments. With the 
TABLE 2

CASE 1: FINANCIAL TRANSFER FROM FOREIGN COUNTRY TO HOME COUNTRY: ELASTIC LABOR SUPPLY

\begin{tabular}{lrrc} 
& \multicolumn{3}{c}{ One Good Case } \\
\cline { 3 - 4 } & \multicolumn{3}{c}{ Period } \\
& 0 & 10 & Steady-State \\
$\mathrm{q}^{*}$ & -1.0 & 0.0 & 0.0 \\
$\mathrm{q}^{*}$ & 1.0 & 0.0 & 0.0 \\
$\mathrm{~K}^{*}$ & 0.0 & -2.5 & -2.8 \\
$\mathrm{p}_{\mathrm{C}} \mathrm{C}$ & 0.0 & 2.5 & 2.7 \\
$\mathrm{p}_{\mathrm{C}}^{*} \mathrm{C}^{*}$ & 4.3 & 4.2 & 4.2 \\
$\mathrm{~L}^{*}$ & -4.9 & -4.8 & -4.8 \\
$\mathrm{~L}^{*}$ & -2.2 & -2.8 & -2.8 \\
& 2.1 & 2.6 & 2.6
\end{tabular}

\begin{tabular}{lrrc} 
& \multicolumn{3}{c}{ Two Good Case } \\
& \multicolumn{3}{c}{$\begin{array}{c}\text { Period } \\
\end{array}$} \\
\cline { 2 - 4 } & 0 & 10 & Steady-State \\
$\mathrm{q}$ & -0.2 & 0.0 & 0.0 \\
$\mathrm{q}^{*}$ & 0.3 & 0.0 & 0.0 \\
$\mathrm{~K}$ & 0.0 & -0.8 & -0.9 \\
$\mathrm{~K}^{*}$ & 0.0 & 1.0 & 1.1 \\
$\mathrm{p}_{\mathrm{C}} \mathrm{C}$ & -5.0 & 4.7 & 4.7 \\
$\mathrm{p}_{\mathrm{C}}^{*} \mathrm{C}^{*}$ & -6.2 & -5.8 & -5.7 \\
$\mathrm{~L}$ & -1.0 & -0.9 & -0.9 \\
$\mathrm{~L}^{*}$ & 1.2 & 1.1 & 1.1 \\
$\Pi$ & 4.5 & 5.2 & 5.4
\end{tabular}

This table shows the effect of a financial transfer from the foreign-country to the home country equal to 40 percent of the initial foreign capital stock. Variables are measured as percentage deviations from the initial steady-state growth path. 
home capital stock unchanged, home GNP rises by the change in the service account $r q * d z$. Consumption rises in proportion to the wealth transfer, with $d C=(\delta-n) q^{*} d z$. Since $\delta=r$ in equilibrium, $d C=(r-n) q * d z$. The trade balance thus worsens in the amount $(r-n) q^{*} d z$ as consumption $r i s e s$, while the service account improves by $\mathrm{r}^{*} \mathrm{q} d \mathrm{z}$. On net, the capital account of the wealth-receiving economy improves by the sum of the service account surplus and trade account deficit: $n q^{*} d z$. In other words, per capita consumption does not rise as much as GNP, and the current account moves into surplus. The per capita saving $n q^{*} d z$ reflects the necessary widening of home holdings of foreign equity required to keep $Z$ constant for future household generations. Note that the current account surplus is matched by an equal deficit abroad.

In summary, the transfer in this case simply affects who consumes, with no effect on how much output is produced or where it is produced. The result will change with alternative specifications of household utility. For example, if as in obstfeld [14], the rate of time discount is a declining function of instantaneous utility, the transferring economy will reduce consumption by more than the transfer, in order to build up wealth to the pre-transfer level.

When there are two goods, but still no leisure, the only result which differs is that the composition of world spending shifts when wealth is reallocated. So long as the marginal propensity to consume home goods is higher at home than abroad, the home terms of trade improves after the transfer. At the initial terms of trade, the transfer raises demand for home goods and lowers demand for 
foreign goods, while supply of each good is fixed. Thus, a terms of trade change is needed to equilibrate these markets. In our simulation, the required change in $\Pi$ is 2.5 percent. The change occurs immediately, and again there are no subsequent dynamic adjustments. The rise in spending at home is just enough to induce a current account surplus of $n\left(q^{*} / \Pi\right) d z$, which equals steady-state widening for $\mathrm{d} z$. Hence $\dot{z}=0$ after the transfer. Clearly, there is no one-to-one relationship between the terms of trade and the current account balance, as is often supposed.

When leisure enters the utility function, the transfer induces income effects on leisure in both countries, and changes in labor supply. This alters the profitability of investment and eventually changes per capita capital stocks. We first consider the one-good case. The simulation results are recorded in Table 2.

As transfer recipient, the home country consumes more leisure and on impact the labor supply falls by 2.2 percent; the donor abroad increases labor supply by 2.1 percent. With current and expected future labor supply diminished at home, current and future short-run capital-1abor ratios rise above the steady-state value. This higher capital intensity translates into a decline in earnings per share. As a result, the shadow price of capital, $q$, falls by one percent and investment slumps. Abroad, higher labor supply reduces the capital-labor ratio, raises $q^{*}$ by one percent and boosts investment.

Unlike the earlier cases, the one-good model with leisure exhibits dynamic adjustment after the transfer. Most importantly, the shifts in labor supply cause a reallocation of world capital. 
At home, the capital stock is too high at the outset, given the rise in leisure; and abroad it is too low. A foreign investment boom results, which is financed in part by domestic purchases of foreign equity (in practice, the purchases could show up in portfolio investment or direct foreign investment). Thus, $\dot{z}>0$ after the transfer. Over ten periods, the investment slump at home draws down the capital stock by 2.5 percent, and the expansion abroad raises the capital stock by 2.5 percent. The model approaches a new steady state as the capital stock movements brings the capital-1abor ratios (but not capital-potential labor ratios) back toward their technically determined steady state values and the equity prices recover. With $Z$ equal to .16 before the transfer and .48 upon the transfer, steady-state $Z$ rises to .51 .

With two goods produced and leisure consumed, we find a moderation of the swings in labor supply, investment and capital formation. The results of the simulation are recorded in Table 2 . Up on impact the income effects on leisure remain but the change in the locus of spending in favor of the recipient country leads to more spending on the home good and a 4.5 percent terms of trade improvement. This increase in $\Pi$ raises the consumption wage. Given our assumptions on the instantaneous utility function, the substitution effect of the real wage increase dominates the income effect, and the fall in the labor supply due to the transfer is moderated. Abroad the lower consumption wage leads to a substitution toward leisure and the rise in labor supply abroad is diminished. As a consequence, the movements in equity prices, investment and capital 
accumulation are smaller than in the one good case. The consumption switch toward the home country is now more powerful because the wealth transfer is not muted by asset price swings.

To summarize, a wealth transfer leads to a one-shot increase in home consumption and one-shot decline in foreign consumption in the no leisure case. If home and foreign goods are imperfect substitutes, the transfer will raise the home terms of trade assuming a higher home marginal propensity to consume domestic goods. If leisure is a normal good, the transfer will result in a fall in manhours worked at home, and a rise abroad. Since the capital-1abor ratio must remain constant in equilibrium, the capital stock eventually falls at home and rises abroad. q provides the signal for a shift in investment. In the one-good case $q$ falls 1.0 percent on impact and in the two-good case, 0.2 percent. In general, the presence of two goods moderates the investment effect, since the home country's terms of trade improvement reduces the leisure-taking effect.

When a transfer is announced in period zero to occur at some future date there are no essential differences from the case of an unanticipated transfer. An expected transfer changes wealth at the time of the announcement by the present value of the transfer and is equivalent to a current transfer with this value. The paths of consumption, accumulation, labor supply and prices in the case of an anticipated transfer are thus the same as for the corresponding current transfer. 
CASE 2: Unanticipated Balanced-Budget Tax Decrease

Next we consider a reduction in the proportional labor tax rate in the foreign country from 36 percent to 18 percent. Government spending adjusts endogenously in order to maintain budget balance.

As in the case of the transfer, a tax cut induces dynamic adjustment only if the labor supply if variable. $-5 /$ Thus in the no-leisure, one-good case the decrease in foreign government spending is exactly offset by a 21.1 percent rise in private consumption triggered by the jump in after-tax human wealth. With consumption higher at all points in time, the marginal rate of substitution in consumption between any two points is unchanged. In the home country no changes occur. In the no-leisure two-good case, the only modification is that the transfer of spending from the government to the private sector worsens the terms of trade for the foreign country ( $\pi$ rises by 20 percent) because by assumption government spending falls only on home goods while private spending falls on both goods. Full consumption at home and intertemporal marginal rates of substitution are unchanged, but the composition of home spending shifts toward foreign goods. Through a higher consumption wage, home wage earners share with the foreign wage earners the resources no longer taxed by the foreign government.

When leisure enters the utility function, a reduction in the foreign labor tax leads to a higher net wage, with a subsitution effect towards 1 isure and an offsetting income effect. In our study the substitution effect dominates because of the presence of non-labor income and an elasticity of substitution greater than 
TAPLI: 3

CASE 2: BALANCEN-BUDGET TAX IIECREASE IN FOREIGN COINTRY

\begin{tabular}{lrrc} 
& \multicolumn{3}{c}{ One Cood Case } \\
& \multicolumn{3}{c}{ Period } \\
& \multicolumn{1}{c}{0} & 10 & Stcady-State \\
& -0.6 & 0.1 & 0.0 \\
$q^{*}$ & 3.0 & 0.4 & 0.0 \\
$K$ & 0.0 & -0.8 & -0.4 \\
$K^{*}$ & 0.0 & 8.3 & 9.6 \\
$p_{C} C$ & -1.4 & 0.1 & 0.6 \\
$p_{C}^{*} C$ & 20.9 & 22.3 & 22.8 \\
$L^{*}$ & 0.5 & -0.4 & -0.5 \\
$L^{*}$ & 8.7 & 9.4 & 9.5
\end{tabular}

\begin{tabular}{lrrc} 
& \multicolumn{3}{c}{ Two Good Case } \\
\cline { 3 - 4 } & \multicolumn{3}{c}{ Period } \\
& 0 & 10 & Steady-State \\
$\mathrm{q}$ & 0.5 & 0.1 & 0.0 \\
$\mathrm{q}^{*}$ & 1.1 & 0.2 & 0.0 \\
$\mathrm{~K}$ & 0.0 & 1.7 & 2.1 \\
$\mathrm{~K}^{*}$ & 0.0 & 3.4 & 4.1 \\
$\mathrm{p}_{\mathrm{C}} \mathrm{C}$ & -1.1 & -0.3 & -0.2 \\
$\mathrm{p}_{\mathrm{C}}^{*} \mathrm{C}$ & 2.0 .8 & 22.1 & 22.4 \\
$\mathrm{~L}$ & 2.0 & 2.1 & 2.1 \\
$\mathrm{~L}^{*}$ & 4.0 & 4.0 & 4.0 \\
$\mathrm{I}$ & 21.6 & 22.2 & 22.3
\end{tabular}

This table shows the effects of a balanced budget tax decrease of fifty percent in the foreign country. Variables are measured as percentage deviations from the initial steady-state growth path. 
one between leisure and goods consumption. $-6 /$ Labor supply initially rises abroad by 8.7 percent, driving the capital-labor ratio below its steady-state level. With a high current and future expected marginal product of capital, the equity price jumps by 3 percent and investment rises.

The transmission of economic effects to the home country is quite limited in this simulation as is clear in Table 3 , but the channels of transmission are important so we trace them in some detail. While in the no-leisure case the consumption increase matched the government spending decrease abroad, now a world excess demand develops at the initial interest rate. Although output rises with the higher labor supply, the rise in investment and the rise in consumption ensure an excess demand for goods. In this case, the interest rate rises by 30 basis points. With interest rates high, future profits are discounted more heavily and home equity prices fall by a slight .6 of one percent, so that investment dips at home. Households see the temporary rise in interest rates and postpone leisure and consumption. Upon impact, the labor supply is one half of one percent higher. With income up and investment down at home, the capital account turns to deficit as home country residents lend to foreigners by purchasing equity. This helps finance the capital stock expansion abroad.

Over time, the capital stock rises abroad and falls slightly at home, until the steady-state capital-1abor ratio is restored. Once again, when two goods are produced and leisure is consumed there is a moderation in the swings in labor supply, investment and capital accumulation. The foreign substitution of goods 
for leisure remains, but the transfer of purchasing power from the government to the private sector leads to a 22.6 percent worsening of the foreign terms of trade because the foreign private sector consumes some home goods. The foreign consumption wage does not rise as sharply as in the one good case because of the terms of trade effect, so the increases in labor supply, equity prices, and investment are moderated.

At home, the terms of trade effect adds a channel of transmission. With a higher consumption wage, leisure falls and the labor supply rises by 2 percent. Instead of a decline in home equity prices and depressed investment which we saw in the one-good case, the opposite now occurs. Labor in both economies shares the benefit of the tax cut, and capital stocks rise both at home and abroad. The increased world savings required to finance the rise in accumulation results from an initial rise in real interest rates.

CASE 3: Technological Improvement in the Foreign Country When an economy or group of economies such as the NIC's adopt more productive technologies and more rigid capital accumulation, what effects will be transmitted to other countries? Will the improving countries capture all the proceeds of their technological advance or will other economies also benefit? In particular, what will happen to the world-wide distribution of productive capacity and to factor returns in the other economies? We can use our model to answer to these questions in the context of a perfectly efficient two-country environment. Obviously, a 
realistic study of OECD adjustment to NIC growth will require careful treatment of special factors in semi-industrialized nations.

We begin with an initial steady-state in which foreign technology is 5 percent less efficient (in the Hicks-neutral sense) than in the home country. We then shock the global economy with a five percent Hicks-neutral improvement in foreign technical efficiency, that restores technological parity between the two countries. The results of the simulation are recorded in Table 4. Upon impact foreign output and the foreign factor returns rise by five percent. At the initial world interest rate, a rise in the foreign equity price and a rise in investment would be needed to eliminate arbitrage possibilities in world equity markets. In the foreign country, with both equity prices and wages up, higher wealth exerts an immediate upward pressure on consumption. The rise in foreign investment and consumption at the initial rate exceeds the production gain. There results on impact an excess of world investment over world saving at the initial interest rate, requiring a rise in the world interest rate.

In the one good case, the rise in the world interest rate is the sole channel for transmission of the shock to the home country. With no leisure-taking in the model, the technology shock will have the following effects. Foreign equity prices are bid up while high interest rates cause a reduction in the home equity price. In the home country, the depressed equity price discourages investment and the capital-labor ratio begins to decline. Foreign investment jumps as entrepreneurs are encouraged to take advantage of the enhanced technological ability, the 
capital-labor ratio begins to rise. At home, the high interest rates encourage households to postpone consumption to take advantage of strong financial returns. Strictly speaking, the high interest rates depress human wealth and home equity prices; the resulting fall in financial wealth leads to lower home consumption. With home saving up and home investment down, the savings are channeled to the foreign country as home savers buy foreign equity. The home country runs a capital account surplus and provides capital that assists in the foreign building effort.

As time passes, the foreign capital-labor ratio approaches a new, higher steady-state value. The growing foreign capitallabor ratio depresses the marginal product of capital, reduces investment demand, and puts downward pressure on the world interest rate. Eventually the fall in interest rates and the low home capital-labor ratio, and the home capital-labor ratio recovers to its initial level.

With leisure in the one-good model, the results are modified only slightly. Table 4 reports the results of this simulation. The technology shock in the foreign country has three effects on labor supply: first, the wealth increase encourages leisure-taking; second, the interest rate increase leads to a postponement of leisure-taking; and third the higher wage discourages leisure-taking. In our simulation the last two effects predominate and the foreign labor supply rises on impact by 1.8 percent. At home, depressed wealth discourages leisure-taking, the interest-rate effect leads to leisure postponement and the wage effect is, of course, absent. Labor supply rises by a modest one-half of one percent. In both 
places, the higher labor supply boosts the marginal product of capital. At home this limits the fall in $q$ and investment, while abroad it adds to the rise in $q$ and investment. At home, $q$ falls on impact by .6 of one percent, investment falls by 4.1 percent and over the first ten years, the capital stock falls by about 1 percent. Abroad, $q$ rises by 3 percent, investment jumps up 16.6 percent and in ten years time, the capital stock is 8.3 percent higher. Households at home own 20 percent of the initial foreign capital stock. A decade of home capital account surpluses raises their foreign equity holdings to 25 percent of the initial foreign equity holdings to 25 percent of the initial foreign capital stock.

In the new steady-state, after capital stocks are fully adjusted and equity prices return to their initial levels, the foreign capital stock rises 9.6 percent and foreign consumption 6.6 percent. Abroad, the product wage is permanently boosted by the technological shock itself so labor supply remains 2.8 percent above its initial level. At home the capital stock never quite returns to its initial level because accumulation of home-held foreign equity leaves wealth and leisure-taking somewhat higher. The capital-labor ratio in production, however, must return to the initial steady-state.

With two goods produced and leisure consumed, the terms of trade provide an added channel of transmission and strikingly different results. What we find is that home equity prices and investment need not be depressed by the foreign technology shock. When foreign technology improves, output and factor incomes rise. An excess supply of the foreign good develops at the initial 
terms of trade, so $\mathrm{p} / \mathrm{p}$ * rises by 3.9 percent upon impact. The change in the terms of trade ensures that home labor shares directly in the technological gain as cheaper imports push up the consumption wage $\left(\mathrm{w} / \mathrm{p}_{\mathrm{c}}\right)$ by 1.5 percent. The rise in the real wage at home causes a substitution away from leisure at home and the fall in leisure-taking abroad is sharply moderated. Unlike the one-good case where home labor supply and the capital stock fall in the steady-state, the rise in the consumption wage ensures that both the labor supply and capital stock will rise in the steady-state. We see in Table 4 that there is a .7 percent rise in each rather than a .5 percent fall as before. Abroad, the extra leisure-taking 1 imits the steady-state rise in the labor supply and capital stock to .9 percent and 7.7 percent respectively. Since the home country capital stock must ultimately grow, the presence of adjustment costs in accumulation ensures that the process of capital accumulation begins immediately.

Over time, both capital stocks grow, though foreign accumulation is at a far more rapid clip. Home households, as before, purchase foreign equity and the home country runs a capital account surplus but the presence of home investment requirements sharply limits capital flows. As the foreign accumulation pushes up foreign output, the terms of trade shift widens to an ultimate foreign deterioration of 7 percent.

To summarize, improved technology in one country leads to rapid capital accumulation in that country and may change the climate for investment in other economies. Effects on investment in the non-improving country and the size of capital account 
TABLE 4

CASE 3: TECHNOLOGICAL IMPROVEMENT IN FOREIGN COUNTRY

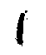

\begin{tabular}{|c|c|c|c|}
\hline & \multicolumn{3}{|c|}{ One Good Case } \\
\hline & \multicolumn{3}{|c|}{ Period } \\
\hline & 0 & 10 & Steady-State \\
\hline$q$ & -0.5 & 0.0 & 0.0 \\
\hline$q *$ & 3.0 & 0.4 & 0.0 \\
\hline$\dot{\mathrm{K}}$ & 0.0 & -0.8 & -0.5 \\
\hline $\mathrm{K}^{*}$ & 0.0 & 8.0 & 9.6 \\
\hline $\mathrm{p}_{\mathrm{C}} \mathrm{C}$ & -1.3 & 0.2 & 0.5 \\
\hline$p_{c}^{*} C^{*}$ & 4.7 & 6.2 & 6.6 \\
\hline L & 0.5 & -0.4 & -0.5 \\
\hline $\mathrm{L} *$ & 1.8 & 2.7 & 2.8 \\
\hline$Z$ & 0.0 & 25.4 & 28.2 \\
\hline
\end{tabular}

\begin{tabular}{lrcc} 
& \multicolumn{3}{c}{ Two Good Case } \\
& \multicolumn{3}{c}{ Period } \\
& 0 & 10 & Steady-State \\
\cline { 2 - 4 } $\mathrm{q}^{*}$ & 0.1 & 0.0 & 0.0 \\
$\mathrm{~K}$ & 2.0 & 0.0 & 0.0 \\
$\mathrm{~K}^{*}$ & 0.0 & 0.5 & 0.7 \\
$\mathrm{p}_{\mathrm{C}} \mathrm{C}$ & 0.0 & 6.3 & 7.7 \\
$\mathrm{p}_{\mathrm{C}}^{*} \mathrm{C}^{*}$ & -0.2 & 0.0 & 0.1 \\
$\mathrm{~L}$ & 3.7 & 6.5 & 7.0 \\
$\mathrm{~L} *$ & 0.5 & 0.7 & 0.7 \\
$\mathrm{I}$ & 1.1 & 1.1 & 0.9 \\
$\mathrm{Z}$ & 3.9 & 6.3 & 7.0 \\
& 0.0 & 4.9 & 6.3
\end{tabular}

This table shows the effects of a 5 percent Hicks-neutral technological improvement in the foreign country restoring technological parity between the two countries. Variables are measured as percentage deviations from the initial steady-state growth path. 
imbalances are shown to depend on the extent of goods substitutability and labor supply elasticity. These results emphasize that discussions of NIC-OECD interactions should focus as much on the process of world capital accumulation as on traditional issues of trade barriers and import penetration.

\section{CONCLUSION}

In this paper we analyze a two-country growth model featuring optimizing agents with perfect foresight. The paper emphasizes the role of asset prices as aggregating information over future events, providing signals for current decision-making, and serving as a channel of transmission of shocks from one economy to the other. The model illustrates many facets of the process of international adjustment. We present simulations of a financial transfer from equity holders in one country to the other, a labor tax decrease in one country and a neutral technological improvement in one country. In each case we consider the importance of imperfect substitutability of home and foreign goods, and of the household's labor-leisure. Two key relative prices are emphasized, the interest rate, as regulator of the savings-investment balance, and the terms of trade, as a crucial determinant of the local supply of labor and the global composition of spending.

In the case of a transfer, anticipated or not, or an unanticipated labor tax change, capital accumulation is altered only when income effects on leisure push labor supplies and capital productivity. Otherwise, these events merely shift purchasing power from one economy to the other, change international spending 
patterns, and move the terms of trade. In the case of a technological improvement, interest rate movements and relative price changes lead to a new pattern of capital accumulation in both countries. The international relocation of capital depends importantly on the strength of terms of trade effects that arise when the pattern of spending shifts, and on labor supply movements that accompany spending shifts.

Many extensions and applications of this model are already completed, and others are planned. Sachs [16] includes oil as an intermediate input in production, adds an oil-exporting region (OPEC) and examines the effects of an oil price increase on growth in the two importing economies. Money is treated as an additional financial asset, to study the interaction of monetary policies, exchange rates, and the accumulation process in a global setting. 
Appendix 1: The Household Maximization Problem

\section{Consumers maximize}

A. 1) $\quad \int_{0}^{\infty} U\left[C\left(C_{D}, C_{M}, 1-L\right)\right] L_{f} e^{-\delta t} d t$

subject to the constraint

$$
\text { A. 2) } \quad \dot{A}=(r-n) A-C_{D}-C_{M} / \pi-w L
$$

We assume that $C$ is homogeneous of degree one in $C_{D}, C_{M}$ and $1-L$. Therefore the price index $p_{c}$ is homogeneous of degree one in II and w. First order conditions for the consumer are:
A. 3)

$$
U^{\prime}(C) C_{1}=\lambda
$$

A. 4)

$$
U^{\prime}(\mathrm{C}) \mathrm{C}_{2}=(1 / \pi) \lambda
$$

A. 5)

$$
\mathrm{U}^{\prime}(\mathrm{C}) \mathrm{C}_{3}=\mathrm{w} \lambda
$$

$$
-\dot{\lambda} / \lambda=(r-\delta)
$$

where $C_{i}$ is the partial derivative of $C(\cdot)$ with respect to the $i^{\text {th }}$ argument. Multiplying the first three of these equations by $\mathrm{C}_{D}, \mathrm{C}_{\mathrm{M}}$ and $(1-\mathrm{L})$ respectively and summing the three we $\mathrm{f}$ ind:

A. 7)

$$
U^{\prime}(C)\left[C_{1} C_{D}+C_{2} C_{M}+C_{3}(1-L)\right]=\lambda\left[C_{D}+(1 / I) C_{M}+w(1-L)\right] .
$$

The price index expressing aggregate consumption $C$, in terms of the domestic good is $p_{c}=p_{c}(1,1 / \pi, w)$. The partial derivatives of $\mathrm{p}_{\mathrm{C}}$ are $\mathrm{p}_{\mathrm{C} 1}=\mathrm{C}_{\mathrm{D}} / \mathrm{C}, \quad \mathrm{p}_{\mathrm{C} 2}=\mathrm{C}_{\mathrm{M}} / \mathrm{C}$ and $\mathrm{p}_{\mathrm{C} 3}=(1-\mathrm{L}) / \mathrm{C}$ by standard duality theory. By Euler's equation, $\mathrm{p}_{C}=\left(\mathrm{C}_{\mathrm{D}} / \mathrm{C}\right) 1+\left(\mathrm{C}_{\mathrm{M}} / \mathrm{C}\right) 1 / \Pi+$ $((1-L) / C) w$. In equation $(A .7)$, left-hand bracket equals $C$ by 
Euler's equation applied to aggregate consumption, and the righthand bracket is $p_{c} \mathrm{C}$ as just derived. Equation (A.7) can thus be rewritten to relate aggregate consumption to its price index.

A. 8 )

$$
U^{\prime}(C) C=\lambda p_{c} C
$$

or

$$
U^{\prime}(C)=\lambda p_{C}
$$

Time differentiating (A.8) and substituting equation (A.6) we get A.9) $\quad \frac{-U^{\prime \prime}(C)}{U^{\prime}(C)} \dot{C}=(r-\delta)-\frac{\dot{p}_{c}}{p_{c}}$ When $U(C)=C^{1-\sigma}$, we get

A. 10) $\quad \sigma \frac{\dot{C}}{\mathrm{C}}=(r-\delta)-\frac{\dot{\mathrm{p}}_{\mathrm{c}}}{\mathrm{p}_{\mathrm{C}}}$ or adding $\frac{\dot{\mathrm{p}}_{\mathrm{c}}}{\mathrm{p}_{\mathrm{c}}}$ to both sides

A.10') $\left(\frac{p_{c}^{\cdot} \mathrm{C}}{\mathrm{p}_{\mathrm{c}} \mathrm{C}}\right)=\frac{r-\delta-(1-\sigma) \dot{\mathrm{p}}_{\mathrm{c}} / \mathrm{p}_{\mathrm{c}}}{\sigma}$

Let the rate of change of the price index $\dot{\mathrm{p}}_{\mathrm{c}} / \mathrm{p}_{\mathrm{c}}$, given to the household at time $t$, be $\Psi$. Integration yields the condition for consumption expressed in domestic goods at time $t$ :
A.11)
$p_{c}(t)$
$C(t)=p_{c}(0)$
$(0) e^{\delta_{0}^{t}(r(s)-n-\delta}$
$(1-\sigma) \Psi(s)) d s d t$

Also we have the requirement that wealth equals the present value of lifetime consumption
A. 12)
$A(0)=\int_{0}^{\infty} e^{-\int_{0}^{t} r(s) d s} p_{c}(t) C(t) d t$. 
Using (A.11) in (A.12) we get

A.13) $\quad p_{C}(0) \quad C(0)=\Re(0) \quad A(0)$

with

$$
1 / \hat{R}(0)=\int_{0}^{\infty} e^{-\int_{0}^{t}\left[\frac{(\sigma-1)(r(s)-\Psi(s))+\delta-n}{\sigma}\right]} d t \text {. }
$$

Hence the time path of $\mathfrak{R}$ is described by differentiation

$$
\dot{\hat{R}}=\hat{R}^{2}-\hat{R}\left[\frac{(\sigma-1)(r-\Psi)+\delta-n}{\sigma}\right], \lim _{t \rightarrow \infty} \tilde{R} e^{-r t}=0
$$

The path of consumption over time is governed by equation (A.14) and the condition that $p_{C}(t) C(t)=\hat{R} A(t)$. The consumer problem is reduced to a two-point boundary value problem with $A$ predetermined at time $t$ and $\vec{R}$ non-predetermined.

When $U(C)=$ Ln $C, \sigma=1$ and the non-predetermined variable $\stackrel{\mathrm{R}}{\mathrm{i}}$ is a constant equal to $\delta$ - $\mathrm{n}$. In this case consumption is proportional to wealth, $\mathrm{p}_{\mathrm{C}}(\mathrm{t}) \mathrm{C}(\mathrm{t})=(\delta-\mathrm{n}) \mathrm{A}(\mathrm{t})$. 
APPENDIX 2: SIMULATION PARAMETERS AND STEADY-STATE VALUES

\section{Parameters}

$$
\begin{aligned}
& \mathrm{d}, \mathrm{d}^{*}=0.08 \\
& \delta, \delta^{*}=0.09 \\
& \mathrm{n}, \mathrm{n}^{*}=0.02 \\
& \mathrm{~b}, \mathrm{~b}^{*}=2.00 \\
& \alpha, \alpha^{*}=0.75 \\
& n, n^{*}=0.60 \\
& \theta, \theta^{*}=1.00 \\
& \tau, \tau^{*}=0.36 \\
& \sigma, \sigma^{*}=2.00
\end{aligned}
$$

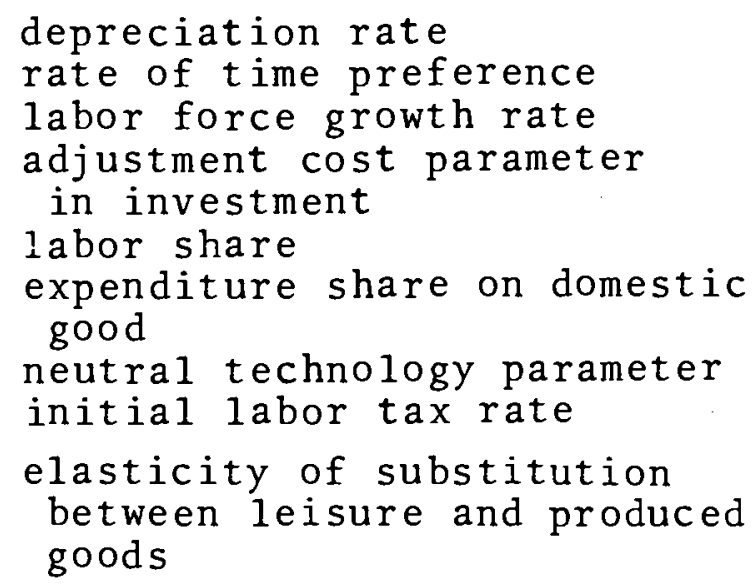
between leisure and produced goods

\section{Initial Steady-State Values*}

One Good Case

$$
\begin{aligned}
\mathrm{q}^{*} & =1.20 \\
\mathrm{q}^{*} & =1.20 \\
\mathrm{~K} & =0.87 \\
\mathrm{~K}^{*} & =0.89 \\
\mathrm{~L}^{*} & =0.62 \\
\mathrm{~L}^{*} & =0.64 \\
\mathrm{Z} & =0.16 \\
\mathrm{R} & =0.09 \\
\mathrm{p}_{\mathrm{C}} \mathrm{C} & =0.61 \\
\mathrm{p}_{\mathrm{C}}^{*} \mathrm{C}^{*} & =0.58 \\
\mathrm{~W}^{*} & =0.82 \\
\mathrm{~W}^{*} & =0.82 \\
\mathrm{I}^{*} & =0.13 \\
\mathrm{I}^{*} & =0.14 \\
\mathrm{H}^{*} & =7.46 \\
\mathrm{H}^{*} & =7.46
\end{aligned}
$$

*These values describe the initial steady-state states for the transfer and labor tax simulations. For the technology shock, with $\theta^{*}$ set at .95 initially, the initial steady-state is slightly different. 


\section{FOOTNOTES}

1/ This procedure is an elaborated form of Newton's method, fully described in [12]. A summary description of the method is provided in section 3 of the text.

2/ In the absence of taxation on corporate or non-labor income, the Modigliani-Miller Theorem assures us that our financing assumption is harmless, and that any mix of financing through debt, new equity, and retained earnings will give the same results.

3) We assume in the simulations that the function $C\left(C_{D}, C_{M}, 1-L\right)$ in the utility function is a nested function which is CES between leisure and an aggregate of produced goods (with elasticity of substitution 2) and that the aggregate for produced goods is

Cobb-Douglas, $C_{D}^{n} C_{M}^{1-\eta} \quad$ (with $\eta=.6$ ).

4/ Without convergence, the improper integral does not exist. For example, on non-convergent paths, the discounted value of future dividends approaches infinity.

5/ In the no leisure case, the steady-state change occurs on impact. The steady-state change in government spending is $\mathrm{dG}^{*}=\mathrm{w}^{*} \mathrm{~L}^{*} \mathrm{~d} \tau *$ and with interest rates set by the rate of time preference the steady-state change in human wealth is $\mathrm{dH}^{*}=\left(\frac{-\mathrm{w}^{*}}{\mathrm{r}^{*}-\mathrm{n}}\right) \mathrm{d} \tau^{*}$.

In the one good case, the fall in foreign government spending is exactly matched by a rise in foreign private consumption (caused by raised human wealth) $\mathrm{dC}^{*}=\left(\delta^{*}-\mathrm{n}\right) \mathrm{dA} *=\left(\delta^{*}-\mathrm{n}\right) \mathrm{dH}^{*}=\left(\delta^{*}-\mathrm{n}\right)\left(\frac{-\mathrm{w}^{*}}{\mathrm{r}^{*}-\mathrm{n}}\right) \mathrm{d} \tau=-\mathrm{dG}$.

No changes occur at home. This effect occurs at the time of the shock, none of the prices in the model change and the steady-state is reached instantly.

In the two good case, the change in foreign aggregate consumption is the same as above but the transfer of spending from the government to the private sector worsens the foreign terms of trade (because government spending falls only on home goods while private consumption is split between the two goods).

6/ On the importance of the substitution elasticity for labor supply decisions, see [3].

7/ This case makes clear the importance of perfect foresight in response to macroeconomic shocks. When $q *$ rises and q falls, all agents anticipate the eventual accumulation of capital abroad and the temporary decumulation at home (they foresee a falling marginal product of capital abroad and expect capital losses; they foresee a rising marginal product of capital at home and expect capital gains). As a result, equity prices and investment 
do not move as sharply as they would if agents mistook the changes as permanent. A comparable model with static expectations rather than perfect foresight is likely to imply a greater vulnerability of the home country to the foreign technology shock. With adjustment costs related to investment ratios, perfect foresight presents unnecessary adjustment costs in both countries. 


\section{REFERENCES}

1. Abe1, Andrew, 1978, "Investment and The Value of Capital," Ph.D. dissertation, Massachusetts Institute of Technology.

2. Abe1, Andrew and Olivier Blanchard, 1980, "An Intertemporal Equilibrium Model of Saving and Investment," Harvard University Discussion Paper No. 739.

3. Atkinson, Anthony and Joseph Stiglitz, 1980 , Lectures in Public Economics, McGraw Hill.

4. Blanchard, O1ivier, 1979, "Dynamic Effects of a Balanced Budget Change in Spending, The Case of Flexible Prices," manuscript, Harvard University.

5. Buiter, Willem, 1979, "Time Preference and International Lending and Borrowing in an Overlapping Generations Mode1," Working Paper No. 352, National Bureau of Economic Research.

6. Fisher, Stanley and Jacob Frenke1, 1972, "Investment, The Two-Sector Model and Trade in Debt and Capital Goods," Journal of International Economics.

7. 1974, "Interest Rate Equalization and Patterns of Production, Trade and Consumption in a Two Country Growth Mode1," Economic Record.

8. 1974, "Economic Growth and Stages of the Balance of Payments," in Free Trade, Stability and Macroeconomics, edited by Horwich and Samuelson, New York.

9. Hamada, Koichi, 1966, "Economics Growth and Long-Run Capital Movements," Yale Economic Essays, Spring.

10. Hayashi, Fumio, 1979, "The q Theory of Investment: A Neoclassical Interpretation," manuscript, Harvard University.

11. Jorgenson, Dale, 1963, "Capital Theory and Investment Behavior," American Economic Review.

12. Lipton, David, James Poterba, Jeffrey Sachs, and Lawrence Summers, 1980 , "Multiple Shooting in Rational Expectations Models," Technical Working Paper No. 3, National Bureau of Economic Research.

13. Lucas, Robert, 1967, "Adjustment Costs and the Theory of Supply," Journal of Political Economy.

14. Obstfeld, Maurice, 1980, "Macroeconomic Policy and World Welfare under Flexible Exchange Rates," Discussion Paper No. 63, Columbia University. 
15. Ruffin, Roy, 1979, "Growth and the Long-Run Theory of International Capital Movements," American Economic Review.

16. Sachs, Jeffrey, 1980, "Energy and Growth Inder Flexible Exchange Rates: A Simulation Study," in The International Transmission of Economic Disturbances under Flexible Rates, edited by J. Bhandari and B. Putnam, forthcoming.

17. Tobin, James, 1969, "A Feneral Equilibrium Approach to Monetary Theory," Journal of Money, Credit and Banking.

18. Treadway, Arthur, 1969, "On Rational Entrepreneurial Behavior and the Demand for Investment," Review of Economic Studies. 